\title{
Naming God Together: Muslim-Christian Theology of Mercy in the Indonesian Context
}

\author{
Albertus Bagus Laksana \\ Sanata Dharma University, Yogyakarta, Indonesia \\ bagus.laksana@usd.ac.id
}

\begin{abstract}
:
Using the method of the new comparative theology, this essay attempts to take the Indonesian context seriously, where the recent and highly divisive religio-political tension has given rise as well to an inclusive public theological discussion of God as the Merciful, and offers an explicit comparative theological analysis of God as Merciful in the Muslim and Christian (Catholic) traditions. On the structural level, these two tradi-tions agree that Mercy has at least three dimensions, namely ontological (mercy belongs to the very being of God), personal (God's mercy is made manifest in paradigmatic human person) and social (mercy has a dynamic of reaching out to others in solidarity). While being formulated and expressed within the confines of each theological system, mercy as God's quality is shown to be at the center of Muslim and Christian naming of God. The two traditions move from philosophical theism to thepersonal and social dimensions of manifesting God's mercy in the world. This comparative theological analysis of God as the Merciful will serve as a responsible public theology in the complex and pluralistic Indonesian society.
\end{abstract}

\section{Keywords:}

comparative theology, mercy, Muslim, Catholic, Indonesia.

\section{INTRODUCTION}

At the end of his bull inaugurating the year of mercy, Misericordiae Vultus, Pope Francis made a novel gesture by venturing into an interreligius theology of mercy, reaching out to Judaism and Islam in particular. 
The Pontiff writes:

There is an aspect of mercy that goes beyond the confines of the Church. It relates us to Judaism and Islam, both of which consider mercy to be one of God's most important attributes. Israel was the first to receive this revelation which continues in history as the source of an inexhaustible richness meant to be shared with all mankind. As we have seen, the pages of the Old Testament are steeped in mercy, because they narrate the works that the Lord performed in favour of his people at the most trying moments of their history. Among the privileged names that Islam attributes to the Creator are "Merciful and Kind". This invocation is often on the lips of faithful Muslims who feel themselves accompanied and sustained by mercy in their daily weakness. They too believe that no one can place a limit on divine mercy because its doors are always open. (Misericordiae Vultus 23; emphasis mine)

Then, the Pope expresses his hope thus:

I trust that this Jubilee year celebrating the mercy of God will foster an encounter with these religions and with other noble religious traditions; may it open us to even more fervent dialogue so that we might know and understand one another better; may it eliminate every form of closed-mindedness and disrespect, and drive out every form of violence and discrimination. (Misericordiae Vultus 23)

As we can see, in broad strokes the Pontiff paints a theology of the name of God that becomes distinctive as it takes into account the Muslim understanding of God as the Merciful. He stresses the universality of God's mercy that becomes an occasion for deeper encounters with other religious traditions. This dialog is aimed not only to understand the mystery of God as mercy, but also to understand one another, a process which results in concrete fruits: eliminating close-mindedness and driving out every form of violence and discrimination.

Pope Francis' points are insightful. Among others, it challenges theologians to do this kind of theology. But, does the desire and vision of the Pope correspond to the current theological discourse or the living spirituality of the Muslims, for example? I will show that it does, both in the context of Indonesian Islam and beyond.

In my view, a comparative theology might be the kind of theology that can creatively respond to the challenge posed by the Pope. In this essay I am interested in pursuing a comparative theological analysis of God's 
mercy in two traditions, Islam and Christianity, by taking the particular socio-religious context of Indonesia and by drawing insights from the larger Muslim world as well. I will describe the particularity of contemporary Indonesia (1), then I will offer an example of the kind of comparative theological practice that can be done in that context (2), and finally I will propose some reflection on the nature of comparative theology in the specificity of the Indonesian context (3).

\section{The Context: Indonesia And Beyond}

At this point it has to be stated that the Indonesian context is distinctive within the larger Islamic world. Of course, Indonesia has too often been hailed as the largest concentration of Muslim population in the world. This statement is quite factual, but what is more problematic is how to see the significance of that fact. Beyond the numbers, Islam in Indonesia is anything but simple. In the past, its richness and particularity as an adapted, localized, or hybridized form of Islam have been taken for granted. However, in the last two decades or so, it has become clear that it is an Islamic society in transition and in tensions, as different styles of Islam vie for influence and domination. Contemporary Indonesia is a heated place of religious negotiation. Since the fall of the New Order Regime (1998), the presence and influence of Islamic Salafi movements with closer connection to the Middle East have become more widespread and political. Some forms of radical Islam have entered the country and gained following. The transnational Hisbut Tahrir has allegedly been able to garner a significant number of followers, including among some most educated layer of Indonesian Muslim population. Most recently ISIS symphatizers have posed not only security problems, but rather a political one due to their rejection of the legitimacy of the Indonesian state as they aspire for trans-national Islam based on the idea of khilafa. The government has only recently taken action by initiating the legal process of dissolving Hisbut Tahrir, while intensifying the fight against ISI.

These Salafi-oriented forms of Islam and the radical political Islamic movements pose a direct challenge to the two largest and most influential Islamic organizations in Indonesia, the modernist Muhammadiyah and the traditionalist Nahdlatul Ulama. As a response, the latter comes up with a religio-cultural program of "Islam Nusantara" ("Archipelagic Islam") emphasizing Islam as blessing to the whole universe (rahmatan 
lil'alamin). This is a creative synthesis of the universal Islam and the local reality of Indonesia as a plural nation-state with its diverse and rich religio-cultural traditions. This framework takes the reality of Indonesia theologically in the understanding of Islam. In this regard, the notion of rahma (blessing, grace, from the word rahim, as one of God's names) becomes not only a purely religious agenda, but rather a political statement about a certain communal way of life. In the particular context of our discussion on the Muslim-Christian theology of mercy, we should not fail to note this political implication of the notion of "rahma" (blessing or mercy).

In this regard, I should mention the most recent political context of the discourse on God's mercy, especially among Muslim thinkers and their communities in Indonesia. Without going into the details, the Jakarta Gubernatorial election in the late 2016 and early 2017 has been considered a landmark in the Muslim-Christian relation in Indonesia, as well as in the complex relation between religion and politics. Mr Basuki Tjahaya Purnama, a devout Christian of Chinese descent, was the incumbent and front runner in the election. Unlike most politicians in the country, Mr Basuki has been hailed as a professional politician with unblemished records in public service, boosted by a personal integrity that is deeply rooted in his Christian faith. A few months prior to the election, however, political machinations of his opponents have succeded in accusing him of blasphemy against the Quran (based on his impromptu statement against using the Quran to score political point, namely preventing the election of a non-Muslim leader). These high level machinations skillfully use radical Islamic mass organization for its purpose and has succeeded in galvanizing many ordinary Muslims into taking action in defense for their Holy Book as well as against the Christian politician and other nationalist forces behind him including the President. Mass rallies were staged for this purpose. As a result, Christian-Muslim relation in Indonesia reached a new level of tension not seen in the last decade or so since the fall of the Soeharto regime. These rallies and sectarian campaigns against Mr Basuki managed to help preventing him from winning the election. And, mainly due to political pressures, among others from radical Islamic organizations and movements, Mr Basuki was then sentenced to two years of imprisonment. This verdict, considered by many as unfair and politically motivated, has led to unprecedented civic movement in support for him, but it was quickly morphing into a larger movement, involving diverse religious groupings, going beyond 
the strictly Muslim-Christian tension, in support for the ideal of the nation, that is, unity rooted in pluralism (Indonesian: kebhinekaan). Very interestingly it has given rise as well to interesting theological conversations among scholars of different religious persuasions. One line of these theological reasonings is the need to develop a theology of love that takes into account the specificity of the current Indonesian context.

In this endeavour, the role of Muslim scholars is quite pronounced, as shown by a flurry of articles on the theme in the major newspaper. ${ }^{1}$ In a way, the naming of God has become a public discourse in Indonesia most recently, particularly in the aftermath of the Jakarta gubernatorial election. The aforementioned civic and peaceful movement is a public expression of the idea of the merciful God and Islam as God's blessing and grace for the whole universe. Ahmad Syafi'i Maarif, one of Indonesia's most respectable Muslim scholar and leader, categorically says:

Based on my limited knowledge of Islam, I have come to the conclusion: the most inclusive framework for Islam is "Islam as rahmatan lil'alamin (God's mercy for the whole universe), not only for believers, but for the whole of humanity, even for the universe. So, everything has to be put in this framework. Otherwise, it is deviant. $^{2}$

In particular Maarif speaks against a misguided "Arabism" as well as the theology of death (misguided martyrdom) that lies behind religious violence and fundamentalism. This style of Islam is at odd with the merciful and universal Islam that, among others, can accommodate the richness of local cultures and traditions, including the ideals of Indonesian nationalism. For him, Islam in Indonesia has not been consistently practiced as a universal blessing (or mercy), for non-Muslims as wel as for the universe. He contends that this is more of a problem for the Muslim community itself where internal conflicts and divisions are rife. ${ }^{3}$ For my purpose in this essay, what we see here is the growing awareness among Muslim theologians on the need to understand God as Merciful, and Is-

1 See, for example, Kompas 15 Juni 2017 on the seminar on tolerance and relgious pluralism; also Kompas May 17, 2017 that publishes an article by Asep Salahudin on the notion of hubb or mahhabah. He argues that love is the core (seed) of religion, of life, of worship, citing Rumi's famous verse: Love is an ocean without shores.

2 http://www.suaraislam.co/buya-syafii-kalau-konsep-islamnya-tidak-rahmatan-lil-alamin-pasti-salah/

3 http: / / www.suaramuhammadiyah.id/2016/08/29/syafii-maarif-islam-kita-belum-rahmatan-lil-alamin/2/ 
lam as God's mercy to all. So, there is an awareness about the theological nature of the problem, namely, the way we name God and the implication of this naming on our lives together, beyond the narrow confines of our own religious community.

The current divisiveness and tensions in the Indonesian society have raised serious concerns and doubts in the minds of many about the hybridity of its cultural traditions and the open-mindedness of its people. In this regard, a properly theological account of God's mercy might provide a theological framework that can account for this pluralities and particularities more deeply. Diverse religious scholars have begun the reflection on the need to give a proper place to the inclusive state-ideology of Pancasila within their religious traditions. We can say that in the current religio-political life in Indonesia, the naming of God becomes a public theology geared toward a theology of inclusivity that can be based on the idea of God as Merciful. There is a growing agreement that a responsible naming of God in the current Indonesian context has to meet this demand of inclusivity. The inclusive idea of Indonesian nationhood has been hailed as the framework of the common good for all religious communities. Thus, this non-theological category has actually become a category of public and civic theology of inclusivity, including the theology of God as Merciful. ${ }^{4}$ A constructive theology done by religious communities together, in ways that are still possible, can push this process further so as to bring fruits that the ever changing Indonesian society needs. A contextual comparative theology, such as a Muslim-Christian theology of mercy, might have a role in this process.

Beyond the context of Indonesia, in my view, our time is a crucial moment in history where Christians and Muslims are at a critical juncture of their religious journey, as they are challenged to have a better understanding of who God is. This is a deeply theological moment. The turns of events in the world have challenged Christianity and Islam in their respective understanding of God. Here the understanding of God as Merciful presents itself in both traditions as particularly rich, which can adequately respond to the challenge of our time. Along this line of thinking, Muslim-Christian comparative theological discourse on God as Merciful can bring these communities together in their response to the common challenge. As Pope Francis suggests, Christians and Muslims

4 This context is markedly different from the European one that Walter Kasper describes, namely, the discourse on the absence of God. Cf. Walter Kasper, Mercy:The Essence of the Gospel and the Key to Christian Life (Paulist Press, 2014), 1-4. 
can name their God together, and comparative theology provides a possible avenue for this.

Before I move to the comparative engagement, let me reiterate my thinking about the specificities of comparative theological method that make it the kind of theology that the pluralistic and complex Indonesian society might benefit from.

First, comparative theological work is theologically constructive. It says something about who God is and how he deals with humanity and the world. This is crucial because religious people often act based on properly "religious" and "theological" reasons, that is, their understanding of who God is and what He wants or enjoins them to do. Among many Indonesian Muslim voters, for example, voting for a Muslim candidate is not a merely civic and political virtue, but rather a religious obedience and conformity that is not only proper but obligatory for Muslims. I remember my conversation with a taxi driver ahead of the aforementioned gubernatorial election in Jakarta in January 2017. While this Muslim driver frankly acknowledged that Mr Basuki Tjahaya Purnama had proved himself to be the most qualified to serve as governor, his Muslim conscience nevertheless compelled him to vote for Mr Anies Baswedan, a Muslim of Arab descent. So, a properly theological account of who God is and His ways of dealing with humanity and the world can be crucial. In the Christian tradition, mercy has been understood as a deeply theological and spiritual virtue, but also civic. Johann Gottfried Lessing writes: "the most compassionate human being is the best human being, the one most disposed to every civic virtue and to all kinds of magnanimity." ${ }_{5}$

Secondly, the comparative learning involved in comparative theology is not only learning about the other, but rather learning from the other religious tradition. So, there is an aspect of togetherness in the enterprise, in the act of paying close attention to the other and incorporating this into the self. Comparative theology is thus a deeply personal act, geared toward spiritual transformation, which is all the more urgent in the comparative work on mercy and given the context and challenge of our time. As will become clearer, mercy is both affective and effective. ${ }^{6}$ It is putting oneself in the shoes of the other, finding what is one's own in the other, and to bear the suffering of other. This is in line with the very

5 Rousseau and Lessing understand compassion as among the most important civic virtues. See Walter Kasper, Mercy, 25.

6 Kasper, Mercy, 23. 
dynamic of comparative theology, namely, to enter into the world of the other. $^{7}$ As Pope Francis suggests, the hope is for a better understanding of God and one another, an understanding that helps to eliminate every form of closed-mindedness and disrespect, and drive out every form of violence and discrimination (Misericordiae Vultus 23).

\section{Muslim Naming of God as Merciful}

The method of comparative theology suggests that we spend some quality time in the other. And in my case, this other tradition is the Muslim tradition, where I need to stay longer in order to be able to feel and understand how the Muslim community reflects on God as the Merciful. In this regard, it has to be noted that there has been a larger, even global, theological movement among Muslim scholars and theologians to explore the centrality of love and mercy. The Common Word movement (2007) initiates this theological exploration on the global level. The Common Word says:

The basis for this peace and understanding already exists. It is part of the very foundational principles of both faiths: love of the One God, and love of the neighbour. These principles are found over and over again in the sacred texts of Islam and Christianity. The Unity of God, the necessity of love for Him, and the necessity of love of the neighbour is thus the common ground between Islam and Christianity. (The Common Word, Abridged Version)

In Indonesia, as mentioned earlier, a number of individual Muslim thinkers, such as Ahmad Syafi'i Maarif, Quraish Shihab, Alwi Shihab, Haidar Bagir ${ }^{8}$, and Zuhairi Misrawi, have begun the work of reflecting on the nature of God in terms of love and mercy. A similar enterprise has also been done by the major Muslim organizations and institutions. As mentioned, the Nahdlatul Ulama has determined to embark on a longterm mission of restoring the notion of Islam (the Quran and the Proph-

7 Elsewhere I call this dynamic as making a "pilgrimage" into the world of the other. See my "Comparative Theology: Between Identity and Alterity," in Francis X. Clooney (ed.), New Comparative Theology: Interreligious Insights from the Next Generation (New York: T \& T Clark, 2010), pp. 1-20.

8 Cfr. Haidar Bagir, Islam: The Faith of Love and Happiness (forthcoming, Kube Publishing Limited); See also his various popular works on Rumi and Ibn Arabi, which are also centered around the idea of love, such as Risalah Cinta dan Kebahagiaan (Bandung: Mizan, 2012); Belajar Hidup dari Rumi: Serpihan-Serpihan Puisi Penerang Jiwa (Jakarta: Noura Books, 2015); Mereguk Cinta Rumi: Serpihan-Serpihan Puisi Pelembut Jiwa (Jakarta: Noura Books, 2016); Semesta Cinta: Pengantar kepada Pemikiran Ibn 'Arabi (Mizan, 2015). 
et Muhammad) as a blessing for the whole universe, an understanding based on the more fundamental notion of God as ar-Rahman ar-Rahim, the Most Gracious and Merciful. As we will examine later, the notion belongs to the core of Islamic tradition, and many distinguished Muslim scholars have reflected on that, for example Ibn Arabi and his school of thought. I will make references to this wider tradition of Muslim reflection on the name of God as the Most Gracious and the Most Merciful, bearing in mind that one of my major concerns in this essay is to find certain reflection on God as Mercy among Indonesian Muslim scholars. ${ }^{9}$

Zuhairi Misrawi, an Al-Azhar educated young Muslim thinker, proposes an Islam with a humanistic horizon, grounded in the theology of tolerance. He writes:

It has to be admitted that, without the doctrine of tolerance, religions will lose their vital energy (elan vital). Tolerance is an expression of heavenly and earthly teaching. In the Islamic tradition, God is called as Al-Salam (the Peace), the All-Forgiving (al-Ghafur), the Most Gracious" (al-Rahman), and the Most Merciful (al-Rahim). So, the main driving force behind tolerance is God. Because it originates in God, we have no choice other than striving to work for tolerance in our lives. ${ }^{10}$

It is very insightful that Misrawi emphasizes the centrality of charity (mercy, love) in the Muslim culture. For him, the Qur'an conveys the message of Love as a continuation and confirmation of the message of love in the previous religious and prophetic traditions. To cull out the message of love in the Quran, Misrawi employs a contextual Qur'anic interpretation based on the fundamental theological notion that God is the Source of Love. What is born is what he calls a theology of "the name of God", which is nothing other than the theology of Mercy because the name of God concerned is the Gracious and Merciful. Another name for this is the theology of basmalah, referring to the formula of "In the Name of God the Most Gracious and the Most Merciful (which is also the first chapter of the Quran, Al-Fatihah).

9 On the Christian side, we have seen some new theological works on mercy, as well as the flourishing devotion to Divine Mercy in many parts of the world, including Indonesia. The Catholic Archdiocese of Semarang has also undersood its mission in the Indonesian pluralistic society in terms of creating the civilization of love and mercy (Indonesian: peradaban kasih).

10 Zuhairi Misrawi, Al-Quran Kitab Toleransi: Inklusivisme, Pluralisme dan Multikulturalisme (Jakarta: Penerbit Fitrah, 2007), 228. 
For Misrawi, the basmalah formula begins the Qur'an, identifying God with His particular names, that is, the Most Gracious and the Most Merciful. Quranic interpreters debate whether the basmalah is actually part of the Quran. Based on classical authorities as well as his own reasoning, Misrawi believes it is part of the Quran. Despite its centrality, the theology and meaning of basmalah for Muslims has very rarely been explored. ${ }^{11}$ As a result, many Muslims begin all the activities with this prayer, but end up doing things that are not in line with the spirit of this prayer. This prayer becomes mere lipservice and accessories, while life is rife with conflicts. ${ }^{12}$

Against this superficiality, Misrawi emphasizes that being gracious and merciful is the path of God, thus being "tolerant" is also part of this path. God creates human beings in order for Him to share His grace and mercy. As stipulated by the Prophet Muhammad, Muslims recites the basmalah when they begin every activity, so that grace and mercy becomes the spirit behind everything they do. ${ }^{13}$ Thus, every act of intolerance and violence would run contrary to this spirit. Since God himself identifies grace and mercy as His name, every human being has to possess this quality in himself. As we can see, Misrawi's theology stems from his underlying concern for tolerance. We will return to this social concern later. In what follows I will delineate the Muslim thinking about mercy in terms of ontology and personal dimension.

\section{Ontology of Mercy}

According to Muslim scholars, this formula "In the Name of God, the Most Gracious and the Most Merciful" (Al-Fatihah) constitutes the apex of monotheistic faith and way of life (shariah). For it confesses the primacy of God, and is in line with the Muslim confession of faith "There is no god but God." For our purpose here, i.e., exploring the Muslim theology of mercy, the names of God mentioned in this basmalah formula, "Al-Rahman and Al-Rahim," are theologically significant.

In the Islamic tradition, al-Rahman is understood as referring to the perfect and unconditional love of God as God. It is a love that does not

${ }^{11}$ As we will see later, this sentiment is also expressed in the Christian context by Walter Kasper who said that despite its centrality in the biblical tradition, mercy has rarely taken a central stage in Christian systematic theology.

12 Misrawi, Al-Quran Kitab Toleransi, 232.

${ }^{13}$ Misrawi, Al-Quran Kitab Toleransi, 10. 
differentiate and permeates all his creation. ${ }^{14}$ Generally, it is taken to be more universal in scope than al-Rahim. As al-Rahman, God loves all humanity with the same love and intensity, and it is a gratuitous gift; that is why al-Rahman only applies to God. ${ }^{15}$ For Muqatil ibn Sulayman (d. 150/767), an early Quranic interpreter, al-Rahman is the Compassionate One, while al-Rahim is the One who deigns to act compassionately. So, it can be said that al-Rahman is an absolute state of the divine, while al-Rahim is a volitional state. Al-Rahman provides existence and sustenance to all creatures while Al-Rahim gives grace and salvation to those who deserve it. ${ }^{16}$ Formulating the difference between the two, Zayd ibn Ali (d. 122/740) is often quoted as saying: "God is the source of mercy for the whole of His creation, and the giver of mercy for His believing servants." 17

A Muslim theologian, M Siraj, cites the Quran where God declares: "Tell My servants that I am indeed the Oft-Forgiving, Most Merciful." (Q 15:49). So, God's mercy is the rule that applies to all and excludes none. The Quran says: "Say: He (Allah) hath inscribed for Himself (the rule of) Mercy. That He will gather you together for the Day of Judgment, there is no doubt whatever. It is they who have lost their own souls that will not believe" (Q 6:12). ${ }^{18}$

While Ar-Rahman is universal, Ar-Rahim is more preferential love, more personal and particular. ${ }^{19}$ Dawud al-Qaysari (d. 751/1350) states that the name Al-Rahim is also comprehensive, but the mercy of $A l-R a$ him is "specific to those existents to whom the command of God extends. It is perfection that is appropriate to the ontological preparation of each one of them." ${ }^{20}$ It is also common to hold that "God is Al-Rahman in this

14 Haidar Baqir, Risalah Cinta dan Kebahagiaan, 41; Abdullah Sani, Filsafat Rahman dan Rahim, 16;

${ }^{15}$ M. Quraish Shihab, Asma’ al-Husna vol. 1 (Jakarta: Penerbit Lentera Hati, 1998), 24.

${ }^{16}$ Sajjad H. Rizvi, "The Existential Breath of Al-Rahman and the Munificent Grace of Al-Rahim: The Tafsir Surat al-Fatiha of Jami and the School of Ibn Arabi," in Mustafa Shah (ed.), Tafsir Interpreting the Quran: Critical Concepts in Islamic Studies (Routledge 2003), 408.

17 Rizvi, "The Existential Breath of Al-Rahman and the Munificent Grace of Al-Rahim, 416.

18 M. A. Siraj, "Mercy of God as Revealed in the Quran and Islamic Scriptures," Word and Worship 49/2 (2016): 135.

19 Abdullah Sani, Filsafat Rahman dan Rahim, 17.

20 Al-Qaysari, Sharh ta'wil al-basmala in Mehmet Bayraktar (ed.), Rasail (Kayseri: Buyuksehir Belediyesi Kultur Yayinlari, 1997), p. 199; quoted via Sajjad H. Rizvi, "The Exis- 
world and Al-Rahim in the afterlife." ${ }^{21} \mathrm{~A}$ famous hadith is very telling in this regard:

God, Mighty and Majestic, possesses 100 mercies, one of which $\mathrm{He}$ sent down to the earth to divide among the whole of His creation so that they might be merciful to one another and show compassion. He retained the remaining 99 for Himself to exercise over His servants on the Day of the Resurrection. ${ }^{22}$

Eschatology is a crucial element in the understanding of God as Al-Rahim, a topic that deserves a treatment of its own. However, one important aspect of Al-Rahim is forgiveness, the fact that God always forgives, including in the hereafter. ${ }^{23}$ In the Quran, there is a combination of ghafur rahim (forgiveness and mercy), that is, God's preferrential love for the sick and the weak (Q 9:91); for those who help their relatives, the needy and the emigrants (24: 22), those who fear Allah (Q 8:69), those who follow the Prophet Muhammad (3:31; 33:73), those who ask for pardon (Q 4: 110), those who do not differentiate among the Apostles of Allah (Q 4:152), even those who state that Allah is "one among three" (such as the Christians; Q 5:74), the strangers/migrants who take refuge in the Islamic realm $(4: 100) .^{24}$

There is also a strand in the Islamic tradition that understand al-Rahman as the Source of Mercy and al-Rahim as the Giver of Mercy. As we can see, this is a talk on who God is in Himself. The school of Ibn Arabi, in particular, develops this ontological reflection of God further. Sajjad Risvi summarizes this differentiation in the thought of Sadr alDin al-Qunawi thus:

tential Breath of Al-Rahman and the Munificent Grace of Al-Rahim”, 417.

${ }^{21}$ Sajjad H. Rizvi, "The Existential Breath of Al-Rahman and the Munificent Grace of Al-Rahim", 416.

22 Al-Tabrisi, Majma' al-bayan, vol. 1, p. 54; cf. Ayoub, The Qur'an and its Interpreters, vol. 1, p. 44; quoted via Sajjad H. Rizvi, "The Existential Breath of Al-Rahman and the Munificent Grace of Al-Rahim", 416.

23 Siraj writes that "Allah's nature is such that he ignores the small lapses and sins as a routine and forgives them but warns against the major evils." The believers should not despair of God's mercy, "for He forgives all sins, for He is oft-forgiving and Most Merciful" (Q 39: 53). Siraj, "Mercy of God as Revealed in the Quran and Islamic Scriptures," 36.

${ }^{24}$ D. Bakker, "The Concept of Rahmah in the Psalms and in the Quran," Bulletin on Islam and Christian-Muslim Relations in Africa 05/01 (1987), 5. 
Al-Rahman is the proper name indicates the absolute being and the source of all existence, and as such acts upon all things. Mercy is existence itself and the act of being merciful is the bestowal of existence. Al-Rahim is a specific name to recipients of special grace but as the particular, it is subsumed in the universal. ${ }^{25}$

In the same vein, Abd al-Razzaq al-Kashani (d. 736/1336) talks about the equivalence of existence and mercy. For him, the Source of Mercy (Al-Rahman) indicates that mercy is so universal and fundamental that it encompasses the believers and the non-believers with existence, sustenance and so forth. ${ }^{26}$

So, mercy does not merely point to the emotive, affective attitude, or compassion, but an ontological fact of bestowing existence. Abd ar-Rahman Jami (1414-1492) writes:

"Know that the mercy of God encompasses everything as a mercy both in reality and in possibility" means that the mercy of God is existence that comprehends everything, encompassing everything with respect to the existence specific to it, and with respect to the possible properties that follow this existence, such as knowledge and ability, and that depend upon its preparedness for existence that follows its existence in (divine) knowledge that precedes its existence in reality. ${ }^{27}$

In the Muslim piety, the idea of God's goodness through the bestowal of all kinds of goodness in the universe is central. In this framework, every sign is a bounty, every sign is a provision. "What man now seeks is the confidence of knowing that at all times the Rahman is behind each reflection in creation. It is said that if a Muslim reads suratu-r-Rahman every day at fajr (daybreak), he will never be afflicted or, if he is afflicted in the eyes of others, he himself will only see the rahma of the Rahman." 28

25 Sajjad H. Rizvi, "The Existential Breath of Al-Rahman and the Munificent Grace of Al-Rahim", 417.

26 Sajjad H. Rizvi, "The Existential Breath of Al-Rahman and the Munificent Grace of Al-Rahim”, 417.

27 Jami, Sharh Fusus al-hikam, pp. 421-2; quoted via Sajjad H. Rizvi, “The Existential Breath of Al-Rahman and the Munificent Grace of Al-Rahim", 418.

28 Sura al-Rahman (Q 55) is often called 'the bride of the Quran' after a hadith related to the Prophet. It is the only chapter of the Quran that begins with ar-Rahman, the divine name. It describes the balance and beauty of the creation of God, and thus, the presence of His Rahma, in terms of pairs: visible human being and invisible jinn, heaven and earth, land and sea, happiness and wretchedness. Shaykh Fadhlalla Haeri, The Mercy of Quran and the Advent of Zaman: Commentary on Four Suras (Zahra Publication, 1986), 75. 


\section{Personal Manifestation of Mercy}

The above explanation shows how the Islamic tradition understands God's essence in terms of His two important names, namely al-Rahman and al-Rahim, the Source of Mercy and the Giver of Mercy. It is in this dynamic of Divine being and acting as well that the Islamic tradition puts the role of Muhammad as God's mercy (rahma) and blessings to the universe: "And We have not sent you, [O Muhammad], except as a mercy to the worlds" (Q 21: 107).

As I mentioned earlier, the notion of Islam as God's blessing (mercy) for the whole universe has come to be emphasized more recently in Indonesia, as part of the theological response to the problem of religious radicalism and conflict. In this line of theological reasoning, Misrawi emphasizes the mission of Muhammad as universal blessing (rahma), not just for Muslims and non-Muslims (humans), but for all religions and the whole of the universe. ${ }^{29}$ The word rahma is a rich one. It means tenderness and care (al-riqqah wa al-ta'aththuf); forgiveness (al-maghfirah) and sustenance (al-rizq). It also points to the many graces of God, such as being saved from trials and tribulations and from the hell fire, victory over adversaries, the bond of love among the faithful, the heaven and abode of peace and so forth. The gift of prophecy is also a form of rahma, as well as the books revealed to Moses. ${ }^{30}$

So, in the person of Muhammad and his prophecy, the Muslim tradition sees how God's mercy is made real in a paradigmatic way. This is what I call the "personal" dimension of divine mercy. Muslims are encouraged to follow the Muhammadan example. This idea is found in popular spirituality books on Muhammad in Indonesia. These books extol the qualities of his personality, especially his virtues that are related to the whole notion of loving mercy, his patience, forgiveness, graciousness, and generosity. In those books, good personal examples abound where Muhammad puts the interests of other as priority. He gare out dirhams to poor woman and his cloth to naked man. ${ }^{31}$

So, the discourse of God's mercy corresponds to the popular Muslim spirituality that is centered around the idea of following the personal example of Muhammad. In a larger context, what is involved here corre-

29 Misrawi, Al-Quran Kitab Toleransi, 241.

30 Misrawi, Al-Quran Kitab Toleransi, 240.

31 Muhammad Mufid, Agar Di Surga Bersama Nabi (Quanta, 2015), passim. 
sponds to what al-Ghazali has writen in his book on the interpretation of the names of God, where he has a section dedicated to the idea of "conforming to the perfections of God most high, and adorning himself with the meanings of His attributes and names insofar as this is conceivable for man." ${ }^{32}$ This is of course akin to the idea of discipleship in Christian theology. For al-Ghazali, those who highly esteem what is revealed in the names and attributes of God will possess a longing, deep desire, to have the quality of God's attributes, in a way that is proper and possible for human being. This desire will be followed by efforts to immitate these qualities. This way, people will become "lordly", companion to angels, and proximate to God. ${ }^{33}$ Al-Ghazali writes:

Man's share in the name of al-Rahim lies in not turning away from any needy persons without meeting their needs to the extent of his ability, nor turning from any poor in his neighbourhood or town without committing himself to them and ridding them of their poverty-either from his own wealth or reputation, or by interceding on their behalf with another. And if he be unable to do all that, he should assist them by prayer or by showing grief on account of their need, in simpathy and love towards them, as though he were thereby sharing in their misfortune and their need. ${ }^{34}$

\section{The Social Dimension of Mercy}

For Misrawi, God's mercy has to be practiced here on earth. ${ }^{35}$ His theology of basmalah is geared toward social practice. If God is the Most Gracious and Merciful, it follows that all His creatures should spread love and mercy. As al-Ghazali has argued forcefully, being merciful ( $\mathrm{ra}$ him) does not only belong to God. That is why Muslims pray the basmalah to begin every deed with the blessing of God as the Most Gracious and the Most Merciful. Sadly, Misrawi observes that many Muslims stress only part of the basmalah (that is, "In the Name of God"), but are rather oblivious to the second part "the Most Gracious and the Most Merciful." 36 However, in his view, the theology of basmalah should go beyond the merely private and individual practice of love and mercy. Beyond

32 Al-Ghazali, The Ninety-Nine Beautiful Names of God (trans. David Burrell and Nazih Daher; Cambridge: The Islamic Texts Society, 1995), $30 \mathrm{ff}$.

33 Al-Ghazali, The Ninety-Nine Beautiful Names of God, 32.

34 Al-Ghazali, The Ninety-Nine Beautiful Names of God, 54-55.

${ }^{35}$ Misrawi, Al-Quran Kitab Toleransi, 234.

${ }^{36}$ Misrawi, Al-Quran Kitab Toleransi, 236. 
the practice of private spirituality, Misrawi proposes the creation of the civilization of the basmalah, that is, a global solidarity for the sake of the common good (Ind. kemaslahatan). Misrawi reiterates:

Prophets and religious communities in the past have made the basmalah as the
moral and ethical foundation for a society of harmony and tolerance. Basmalah
is the majestic expression of God's love for the human family and the whole
universe. The previous prophets were convinced of the truth of the basmalah and
they spread it under different terms. The essence is God as the source of love
and mercy (Ind. kasih sayang). ${ }^{37}$

Overall, Misrawi's theology of the basmalah is deeply contextual, centered around the notions of tolerance and peace, as well as pluralism and multiculturalism. He talks at length about particular problems that have beset Muslim communities in Indonesia, sucah as their discrimination and enmity against the Christians, the bad habit of labelling other groups as infidels and persecuting them, not only Christian and Jewish communities, but also other Muslim minority communities such as the Ahmadiyyah. ${ }^{38}$

Misrawi also identifies the need for religious communities to come together around commonalities (kalimatun sawa'; QS 3:64), namely, worshipping only God, against all kinds of idols. Working in the context of Indonesia, Misrawi believes that the inclusive state-ideology of Pancasila is the kalimatun sawa' among religious communities. In this framework, the unicity of God is made deeply correlated with the principles of universal humanism, unity among fellow citizens, democracy, and social justice. ${ }^{39}$

In conclusion, what I have sketched above, despite its brevity, shows a dynamic understanding of God as the Most Gracious and Merciful in the Islamic tradition, especially in contemporary Indonesia. I am aware that I have not done justice to the many facets of that rich understanding of God in the Muslim tradition. For the sake of systematic comparative purpose, I have limited my analisis on the three salient dimensions of the theology of the name of God as the Most Gracious and Merciful, namely, ontological, personal and social dimensions.

\footnotetext{
${ }^{37}$ Misrawi, Al-Quran Kitab Toleransi, 231.

${ }^{38}$ Misrawi, Al-Quran Kitab Toleransi, 373-450.

${ }^{39}$ Misrawi, Al-Quran Kitab Toleransi, 14.
} 


\section{Christian Naming of God}

Any discourse on mercy in Catholic theology recently cannot be separated from what Pope Francis has been doing in the past few years, namely, the message of God as mercy that has become the hallmark of his papacy. ${ }^{40}$ But his works on mercy are not done in isolation. Mercy has been a central work in Christian theology in general, and a few contemporary Catholic theologians had done works on the theme, among others Walter Kasper, from whom Pope Francis also drew some major inspirations. ${ }^{41}$ What Pope Francis has achieved is giving new impetus, a sense of urgency to this movement of naming God as Mercy beyond the confines of the Church. In particular, his invitation to reflect on the meaning of mercy in the Muslim and Jewish traditions, creates what I want to call "a comparative theological moment" to which this essay also responds.

Following the tripartite divisions of the previous discourse on the theology of God as mercy in the Islamic tradition, I will also take up the ontological, personal and social dimensions of mercy in the Christian tradition.

\section{Ontology of Mercy}

In the Christian tradition, mercy has been understood as related to the very identity of God (who God is, His very identity), as well as what He does, namely, His Self- revelation, including the reason and manner of His dealing with the world and the human family. In a nutshell, mercy belongs to the core of the Trinitarian God. Pope Francis begins the exhortation letter Misericordiae Vultus (MV) by summing up the whole dynamic of Christian Revelation of God as Mercy:

We need constantly to contemplate the mystery of mercy. It is a wellspring of joy, serenity, and peace. Our salvation depends on it. Mercy: the word reveals the very mystery of the Most Holy Trinity. Mercy: the ultimate and supreme act by which God comes to meet us. Mercy: the fundamental law that dwells in the heart of every person who looks sincerely into the eyes of his brothers and sisters

${ }^{40}$ For the limited purpose of this essay, I consult only two works of Pope Francis on mercy, namely, MisericordiaeVultus (the bull of Indiction of the Extraordinary Jubilee of Mercy and his interview with journalist Andrea Tornielli, The Name of God is Mercy (Bluebird Books for Life, 2016).

${ }^{41}$ See various recent works of Walter Kasper on mercy, such as Mercy: The Essence of the Gospel and the Key to Christian Life (Paulist Press, 2013) and "Mercy - The Name of Our God," Louvain Studies 39/3 (2015-2016): 205-217. 
on the path of life. Mercy: the bridge that connects God and man, opening our hearts to the hope of being loved forever despite our sinfulness (MV 2).

Again, mercy belongs to who God is; and how God reveals himself, how he deals with creature and creation. Thus, it encompasses ontology and history understood as the unfolding of God's revelation. The Pope goes on to say:

It is proper to God to exercise mercy, and he manifests his omnipotence particularly in this way".[5] Saint Thomas Aquinas' words show that God's mercy, rather than a sign of weakness, is the mark of his omnipotence. For this reason the liturgy, in one of its most ancient collects, has us pray: "O God, who reveal your power above all in your mercy and forgiveness ..."[6] Throughout the history of humanity, God will always be the One who is present, close, provident, holy, and merciful (MV 6).

The last line is insightful, since it goes beyond a metaphysical theism, combining the many attributes and qualities of God, such as being present, close, provident, holy, and merciful. God is omnipotent, as affirmed in philosophical theism, but this quality is not understood philosophically as an abstract and static quality of God, but rather as belonging to a God who is near and providential. The Pope continues to use the biblical notion of God, rather than the philosophical one:

In short, the mercy of God is not an abstract idea, but a concrete reality with which he reveals his love as of that of a father or a mother, moved to the very depths out of love for their child. It is hardly an exaggeration to say that this is a "visceral" love. It gushes forth from the depths naturally, full of tenderness and compassion, indulgence and mercy ( $M V 6)$.

Walter Kasper, on his part, believes that the Hellenistic idea of God as Being itself has to be reconciled with the biblical revelation of God. For him, there should be no separation between the God of the philosophers and the God of Abraham, Isaac, and Jacob. In this regard, Kasper draws insights from Augustine and Bonaventure. The Being of God is, for Augustine, Love, the essence of the Trinitarian God. Bonaventure, according to Kasper, understands that "God is Being Itself, but Being Itself that communicates itself and exudes itself in love. He goes on to say: "With this definition of God, the philosophical understanding of God was not given up, but it was qualified theologically, concretized, and-in 
the terminology of Thomas Aquinas-determined." ${ }^{42}$ But Kasper notes that in academic theological discourse of God as Being Itself, more particularly in the discussion of God's attributes, mercy has found no place, while the biblical revelation holds that mercy is so central to who God is. So, Kasper writes:

Therefore, it cannot be treated, as happens in the dogmatic handbooks, as one attribute of God alongside others. It certainly cannot be treated as an attribute that is subordinated to the attributes that derive from the metaphysical essence of God and then is mentioned almost only in the margins. Instead, mercy is the externally visible and effectively active aspect of the essence of God, who is love (1John 4:8,16). Mercy expresses God's essence, which graciously attends to and devotes itself to the world and to humanity in ever new ways in history. In short, mercy expresses God's own goodness and love. It is God's caritas operativa et effectiva. ${ }^{43}$

Thus, according to Kasper, "we should treat mercy not as an appendix to the exposition of God's attributes, but rather as the organizing center of God's attributes, with the other attributes grouped around it." Furthermore, the names and attributes of God are coextensive with God's essence. And if mercy is the fundamental attribute of God, then it cannot be understood as an instance of justice. On the contrary, Kasper reasons, divine justice has to be understood within the framework of God's mercy.

Pope Francis stresses that God's Mercy endures forever. Mercy is behind everything that God has done with creation. In this regard, Kasper cites Yves Congar's work on the centrality of mercy in the theology of Aquinas. In the words of Kasper, Congar offers an ontology of love this way:

For if God is the reality that defines everything, then what follows from the assertion "God is love" is that love is the ultimate meaning of the world. Therefore, in an ontology of love, neither can the self-contained substance-as in ancient and medieval metaphysics - nor the subject—as in the modern era-be the reality that defines everything. ${ }^{44}$

42 Kasper, Mercy, 88.

43 Kasper, Mercy, 88

44 Yves Congar, “La misericorde: Attribute souverain de Dieu," La Vie Spirituelle 106 (1962): 380-95; Kasper, Mercy, 90. 
In Christian theology, the ontology of love (and mercy) becomes distinctively Christian as it is related to the mystery of the Trinity. Kasper writes:

The doctrine of the Trinity is no addendum and certainly no antithesis to monotheism; it is monotheism in concrete form. In the doctrine of the Trinity, the abstract philosophical definition of God, according to which God is Being Itself, is concretized and qualified. It says: as Being Itself, God is Love, which communicates and bestows itself as a gift to others. ${ }^{45}$

In the theology of Augustine and Bonaventure, God is understood as the Good One who communicates and bestows himself as a gift (bonum est diffusivum sui). So, within this framework, one can understand why the one God is at the same time triune. "From eternity he has a beloved and a co-beloved; he is thus God as Father, Son, and Holy Spirit. In the spirit of the New Testament, God's being must be defined more precisely as Triune Being in love." ${ }^{46}$

\section{Personal Dimension}

Within the dynamics of the revelation of God as the Trinity, Christian theology can assert that Jesus is the face of the Father's mercy. Pope Francis begins his Misericordiae Vultus thus:

Jesus Christ is the face of the Father's mercy. These words might well sum up the mystery of the Christian faith. Mercy has become living and visible in Jesus of Nazareth, reaching its culmination in him. (MV 1)

By saying that Jesus is the face of the Father's mercy, the Pope directs the dynamic argument to the Person of Christ and Christian discipleship. The $M V$ goes in length narrating the many facets of Jesus' life and work in terms of mercy (Nos. 7-9). Jesus' life expresses God's unbounded forgiveness, reaching out to those who are desperate of it: the outcast, the lost ones, and the sinners. In the Gospels, mercy serves as the criterion to ascertain who God's children are (MV 9). In the Gospel of Luke, this idea of God as merciful is most beautifully expressed in the parables (e.g. Luke 15: 1-23). For Kasper, the Gospel of Luke is particularly insightful in this regard:

${ }^{45}$ Kasper, Mercy, 92.

${ }^{46}$ Kasper, Mercy, 92; cf. Bonaventure, The Mind's Journey to God, VI.1. 
Where Matthew speaks of the perfection of God (Matt 5:48), Luke speaks of God's mercy (Luke 6:36). So for Luke, mercy is the perfection of God's essence. God does not condemn; rather he pardons, he provides and gives gifts in a good, compendious, full, and overflowing measure. God's mercy is, so to speak, superproportional. It exceeds every measure. ${ }^{47}$

In my view, the Pope's reading of the Jesus event (the biblical witness) is perhaps not entirely new, but its distinctive strength comes from the larger theological argument of Mercy as the principal way of God's dealing with humanity, and the personal and social ramification of this on the part of the Christians. Pope Francis argues: "Just as he is merciful, so we are called to be merciful to each other" (MV, 9).

\section{The Social Dimension of Mercy}

In talking about mercy, Pope Francis emphasizes concreteness over abstract ideas. That is why it is crucial to see that the Mercy of God the Father takes on a concrete human face in Jesus. The principle at work here is that "reality (concreteness) takes precedence over ideas, while time takes precedence over space." Along this line of thinking, Walter Kasper talks about "open eyed spirituality" as spiritual consequences of the understanding of God as mercy, namely, "to see our brothers and sisters who are in misery and recognizes Jesus in them." ${ }^{48}$ Kasper takes up the paradigm of the parable of the Good Samaritan. Here mercy is a neighborly virtue, namely, what we do to those who live and interact with us, especially those who need our assistance in particular situation. Mercy goes beyond the confines of family bonds, friendship, religious or ethnic membership. ${ }^{49}$ That is why the Good Samaritan figure has become a symbol of true compassion that has an appeal beyond the Christian communities and has reached the secular culture. But Kasper warns that what this parable is all about is not the same as secularized "universal humanism." This is because it elucidates the behavior of Jesus as an expression of the Father's mercy in heaven. ${ }^{50}$

Taking the context of contemporary Europe, Kasper talks about the relevance of the works of mercy in terms touching on the problems of

${ }^{47}$ Kasper, Mercy, 68.

${ }^{48}$ Kasper, "Mercy - The Name of Our God," 216.

${ }^{49}$ Kasper, Mercy, 70.

${ }^{50}$ Kasper, Mercy, 71. 
immigration (refugees), material and spiritual poverty (loneliness, inner emptiness), the question of divisions and the cohesion of communal life, as well as the politics of peace (war, armed conflicts, arms trade).$^{51}$ Very clearly, Kasper proposes the larger idea of the creation of the culture of mercy that touches upon the political dimension of mercy. In the same vein, the local Catholic archdiocese of Semarang, in Central Java, has also taken up this notion of creating the civilization of love (Ind. peradaban kasih) as its mission in the context of Indonesian pluralistic society.

To cultivate mercy and to be in touch with the reality of God's mercy, the Pope urges the habit of silence and the practice of making pilgrimage (MV 14). The two go together; and interestingly, places of pilgrimage often serve as a place where the power of God's mercy is so inclusive that it attracts pilgrims across religious affiliations. My comparative theological work in the past has touched on this theme, namely the dynamics of interreligious encounters in the context of making pilgrimages to local shrines. ${ }^{52}$ What I found was that in those sacred places, the hearts of people are so receptive toward the mercy of God that unites pilgrims of different religious backgrounds. Many sacred spaces and shrines have become an inclusive place of mercy.

\section{Naming God Together: Comparative Points}

In most cases, comparative theological work begins with the choice of the comparativist herself regarding the texts or themes to compare, in response to the plurality of religions traditions and their interactions today. ${ }^{53}$ In this essay, the choice has not primarily stemmed from me as the comparativist, but is necessitated more by context, that is, by what I consider to be the most urgent need in the current encounter between Christianity and Islam in Indonesia, Asia and beyond, within the larger context of religious radicalism and exclusivism. As we have seen, theo-

${ }^{51}$ Kasper, Mercy, $181 \mathrm{ff}$.

52 See my work, Muslim and Catholic Pilgrimage Practices: Explorations through Java (Routledge, 2014); also my essays on the theme: "Multiple Religious Belonging or Complex Identity? An Asian Way of Being Religious," in Felix Wilfred (Ed.), Oxford Handbook of Christanity in Asia (Oxford University Press, 2014), pp. 493-509; "Back and Forth Riting: The Dynamics of Muslim-Christian Encounter in Shrine Rituals," in Marianne Moyaert and Joris Geldhof (eds.), Ritual Participation and Interreligious Dialogue: Boundaries, Transgressions and Innovations (London, New York: Bloomsbury, 2015), pp. 109-121.

53 Cf. Francis X. Clooney, S.J., Comparative Theology: Deep Learning Across Religious Borders (Wiley-Blackwell, 2010), passim. 
logians of both sides have already been working toward that goal. While working separately, they seem to have agreed to address the common challenge, namely defining who God is in response to the reality in which they live. So, in a sense, their work on mercy is a journey together already, before any comparative theological work on the theme is developed such as in this essay.

So, what I have attempted to do in this essay is simply placing the works of these Muslim and Christian theologians side by side, being attentive to the major dynamics of similarity between them (from ontology to personal and social dimension of mercy). While we might find some interesting and refreshing theological insights in each tradition's reflection on God as Mercy that have been hitherto unexplored, the most significant meaning and power of this theological reflection does not primarily lie in each tradition's discourse as a separate entity, but rather at the moment when we see how these two traditions meet in their naming of God as Mercy. This is akin to a kairos moment, a theological awareness that helps in ushering in a new beginning in the way we live together as religious people and communities.

In what follows I flesh out what I consider to be the major comparative theological points and insights that we gain from previous analyses, namely, the ontological, personal and social dimension of God as Mercy.

\section{Ontology of Mercy: God is Mercy}

The previous analyses show how both Muslim and Christian traditions talk about mercy and love (loving mercy, misericordia) as essential to the nature of God or the Being of God. This ontological reflection of mercy is a theology proper, because it is an act of naming God in a particular way. Mercy is God's name, and mercy belongs to the essence of God's Being. In both traditions, there is also a sense that mercy is not one quality among many qualities or attributes of God. The Islamic tradition holds that only God is al-Rahman. Based on the Quran (17:110), Al-Ghazali argues that "in this respect [Al-Rahman] is close to the name of God most high which functions like a proper name [Allah], although it is definitely derived from mercy [rahma]." ${ }^{54}$ Due to the centrality of

54 Al-Ghazali, Ninety-Nine Beautiful Names of God, 54. On his part, while working in the Akhbarian tradition, al-Khashani writes: "The Source of Mercy (al-Rahman) is a name for God considered in the totality of the names that are in the divine presence, and from which existence flows forth bestowing perfections on all contingent beings." Rizvi, "The Existnetial Breath of Al-Rahman," 420. 
basmalah, the names al-Rahman and al-Rahim (that also include other attributes or names) have certain ontological priority. On the Christian side, Kasper believes that mercy is the basic attribute of God, and organizing center of God's attributes, with the other attributes grouped around it. ${ }^{55}$

In both traditions, the universalism and unconditionality of mercy also stems from this ontological nature. There are strands of thought in both traditions that God's mercy has to do with the essence of all reality, God's creation, and thus has cosmic dimension is also stressed, for example in the thought of Thomas Aquinas (Augustine and Bonaventure as well) and Ibn Arabi. In this regard, the Muslim tradition is using the term "al alamiin" and the ontological reflection of mercy by the school of Ibn Arabi.

In this regard, it has to be noted each tradition does the theology of naming in a way that is quite specific to its own tradition. While the Islam traditions tends to focus on the name of God, which is a proper theologizing in this tradition (due to the paradigmatic "the most beautiful names of God" (al-asma al-husna), Christian theologians typically resort to the Triune God and argue that the essence of the Trinity is the dynamism of mercy. In Misericordiae Vultus, Pope Francis starts with the trinitarian Christology: Jesus Christ is the face of the Father's mercy. On his part, Kasper argues that mercy is the mirror of the Trinity. ${ }^{56}$

Another important point is that both the Muslim and Catholic theologians are deeply aware of the gap between the centrality of mercy in the understanding of God and the actual place of mercy in their respective theologies and communal religious life and practice, hence the urgency to reflect and act. Both sides realize the need to minimize the gap. Here, an important comparative theological insight that I have not been able to address more fully is the notion that God's mercy takes precedence over justice. As Pope Francis has indicated, an unhealthy notion of God's justice can stiffle mercy: "The temptation, on the one hand, to focus exclusively on justice made us forget that this is only the first, albeit necessary and indispensable step" (MV 10). Exploring this notion by engaging the Muslim tradition would be more than interesting in the contemporary context of Indonesia, where the idea of fighting for God's justice seems to be gaining grounds among some groups.

${ }^{55}$ Kasper, Mercy, 90.

${ }^{56}$ Kasper, Mercy, $91 \mathrm{ff}$. 


\section{Personal Manifestation of Divine Mercy}

As we have seen, there are solid theological insights on which Muslims and Christians agree on the nature of God as mercy. However, this similarity does not obliterate each tradition's theological specificity. Christian theology of mercy becomes specifically "Christian" in relation to the Person. Jesus Christ is the personal human face of the Father's mercy. In a way that fits its own theology, the Muslim tradition stresses Muhammad as a paradigmatic and exemplary personal manifestation of God's mercy in history. Always in relation with the Quran that is revealed to him, the Prophet Muhammad is considered to be God's blessing (mercy and love) for all the universe.

In this sense, both traditions go beyond the language of ontology and metaphysics and enter into the dynamics of God's mercy in the particularities of history. ${ }^{57}$ Both traditions seem to challenge us to move beyond the narrow framework of philosophical theism to develop more integral cosmology as well as more authentic theological anthropology by taking a fuller account of God as the Merciful.

This personal dimension of God's unfolding mercy in history gives rise to the idea of discipleship of Christ or following the example of $\mathrm{Mu}$ hammad. Mercy becomes a crucial theme for any contemporary Muslim and Christian spirituality, understood as a cultivation of the heart and the corresponding spiritual-ethical life. Al-Ghazali argues: "for knowledge is the seed of longing, but only to the extent that it encounters a heart freed from the thorns of the passions, for unless the heart be empty the seed will not bear fruit." ${ }^{8}$ Here, we might recall that comparative theology should also result in the spiritual and personal transformation of the comparativits and their communities.

\section{Social Dimension of Divine Mercy}

It has been made very clear that in both traditions, the theology of mercy has serious implication on social issues. The Muslim theology of

${ }^{57}$ Here I see a potential of doing comparative theological work on the special role of the heart in Islam and Christianity. On this, see my dissertation Journeying to God in Communion with the Other: A Comparative Theological Study of the Muslim and Catholic Pilgrimage Traditions in South Central Java and their contributions to the Catholic Theology of 'Communio Sanctorum', Boston College, 2011 (published by Proquest, Ann Arbor, Michigan), p. $532 \mathrm{ff}$.

${ }^{58}$ Al-Ghazali, The Ninety-Nine Beautiful Names of God, 32. 
basmalah, understood within the paramater of monotheistic belief in and surrender to the One God, leads to the call against the worship of non-God, such as materialism, politicization of religions, self-love and so forth. Muslim theologians speak about the creation of the civilization of the basmalah, a global solidarity based on God's universal mercy. In the same vein, Pope Francis and Kasper have not only reiterate the traditional social teachings of the Church on various societal issues, but also give it a new impetus by putting them within the refreshing framework of God's mercy. It is through this lens that they take up the new challenges that have come from our contemporary society in many refreshing and energizing ways, among others by inviting collaborations with other religious communities.

As we have seen, the contemporary Indonesian context poses its own challenges for any publicly responsible theology of God's mercy. The welfare and unity of the country as a deeply pluralistic nation has become a criterion for this public and interreligious theology of mercy. In line with the warning of Kasper that this public expression of God's mercy should not be taken as merely "universal humanism" without theological grounding, Indonesian religious thinkers and scholars seem to agree that theological naming of the One God (as stipulated by the State-Ideology of Pancasila) is crucial in this endeavor.

\section{Reflections on Comparative Theology in the INDONESIAN CONTEXT}

At the end of this essay, I would like to offer some notes on comparative theology in the Indonesian context.

First, the new comparative theology presents itself as the kind of theology that the contemporary context of Indonesia needs. In particular, the "theological" character of this theology is proper, because of the rise of certain "theology" in public (radical theology) that has been countered by a different kind of theology, which is more universal and inclusive, yet localized as well. So, there is something theological that is at stake in the religious discourse in contemporary Indonesia. In general, Indonesians take religions and theology seriously, and the first principle of the state-ideology of Pancasila has a very clear theological import, namely, belief in the One God.

So the context seems to reinforce the term "comparative theology". This is more so if we take Islam, as I do, as the main partner. Contempo- 
rary Muslim thinkers in Indonesia might have their own preferences in naming what they are doing (religious studies, theology, exegesis, etc). But I have not seen a shared repudiation of the term "theology." In my view, although the term "theology" might not always be in the lips of these thinkers, what they mostly do is theologizing, ranging from interpreting the Quran and the Hadiths, to making or interpreting religious laws. In other words, they take God's revelation and Muslim tradition seriously. What is rather different, compared to the Christian theology in the West, is perhaps the relative absence of philosophy and other branches of social and humanistic sciences as background theories or interdisciplinary partner. It has to be noted, though, that many younger Indonesian Muslim intellectuals have developed this interdisciplinary approach to Muslim thinking.

Secondly, the full-fledge practice of the new comparative theology as a distinct field by Muslim theologians is very rare. To date, most works by Muslim scholars have been on interreligious encounters, touching on the dynamics of socio-political interaction between these religious communities, but these works rarely touch on theology proper. The discipline of comparative religion (Ind. Ilmu Perbandingan Agama) has also been practiced in some Muslim quarters, but in ways that tend to be 'objective', too superficial and lacking both depth and vision, involving no theological enrichment and spiritual transformation on the part of the scholars and their communities. Theology of religions is also a related field that is flourishing among Muslim theologians recently. In this kind of works, there are some insights that can potentially be taken as material for comparative theological engagement. It has to be noted as well that a few Protestant theologians have begun some serious works engaging Christian and Islamic theological traditions without necessarily naming their endeavor comparative theology. ${ }^{59}$

Third, while the practice of comparative theology is needed, one has to be aware of the sensitivity of the subject. Artful prudence is needed to practice comparative theology with Islam especially in public square. Comparison between Islam and Christianity has been very sensitive to many ordinary Indonesian Muslims. This kind of discussion, even the scholarly one, can be easily perceived as blasphemy within certain polit-

59 Cfr. Bambang Subandridjo, Eikōn and A yat: Points of Encounter between Indonesian Chritian and Muslim Perspectives on Jesus (doctoral dissertation, Vrije Universiteit, Amsterdam, 2007); Wahyu Satrio Wibowo, Jesus as Kurban: Christology in the Context of Islam in Indonesia (doctoral dissertation, Vrije Universiteit, Amsterdam, 2014). 
ical context. The idea of mutual borrowing or influences between religious communities, including Islam and Christianity, remains theologically sensitive to certain groups of Indonesian Muslims. A theology that is built on the interactions between religious communities can easily be understood as syncretistic as well, a word that is considered an anathema by those groups. To make the situation worse, the Indonesian state has continued to uphold a slippery blasphemy law despite the objections of many groups. In the recent controversy involving Mr Basuki Tjahaya Purnama, some intellectuals have expressed their fear that the arbitrariness of the enforcement of this law might eventually be used to criminalize any scholarly comparative works involving Islam, including the discipline of comparative religion and theology. As a result, it is getting harder for non-Muslim scholars, including Catholic comparativist like myself, to take up Islamic themes for wider public consumption. The good thing is that collaboration, both scholarly and beyond, with Muslim scholars and their communities is a must. So, perhaps, any practice of comparative theology between the Islamic and Christian traditions in the Indonesian context has to be "collaborative" in order to be truly "comparative." And this is not a bad thing.

\section{Bibliography}

Bagir, Haidar. Islam: The Faith of Love and Happiness. Forthcoming, Kube Publishing Limited.

. Risalah Cinta dan Kebahagiaan. Bandung: Mizan, 2012.

Bakker, D., "The Concept of Rahmah in the Psalms and in the Quran," Bulletin on Islam and Christian-Muslim Relations in Africa 05/01 (1987), 1-7.

Clooney, Francis X. Comparative Theology: Deep Learning Across Religious Borders. Wiley-Blackwell, 2010.

Pope Francis. Misericordia Vultus. The Bull of Indiction of the Extraordinary Jubilee of Mercy.

. The Name of God is Mercy. Bluebird Books for Life, 2016.

Al-Ghazali. The Ninety-Nine Beautiful Names of God. trans. David Burrell and Nazih Daher. Cambridge: The Islamic Texts Society, 1995.

Haeri, Shaykh Fadhlalla. The Mercy of Quran and the Advent of Zaman: Commentary on Four Suras. Zahra Publication, 1986. 
Kasper, Walter. Mercy: The Essence of the Gospel and the Key to Christian Life. Paulist Press, 2013.

."Mercy - The Name of Our God," Louvain Studies 39/3 (2015-2016): 205-217.

Laksana, Albertus Bagus. Muslim and Catholic Pilgrimage Practices: Explorations through Java. Routledge, 2014.

.Multiple Religious Belonging or Complex Identity? An Asian Way of Being Religious," in Felix Wilfred (Ed.), Oxford Handbook of Christanity in Asia. Oxford University Press, 2014. Pp. 493-509.

. "Back and Forth Riting: The Dynamics of Muslim-Christian Encounter in Shrine Rituals," in Marianne Moyaert and Joris Geldhof (eds.), Ritual Participation and Interreligious Dialogue: Boundaries, Transgressions and Innovations. London, New York: Bloomsbury, 2015. Pp. 109-121.

Journeying to God in Communion with the Other: A Comparative Theological Study of the Muslim and Catholic Pilgrimage Traditions in South Central Java and their contributions to the Catholic Theology of 'Communio Sanctorum', Boston College. Ann Arbor, Michigan: Proquest, 2011.

. "Comparative Theology: Between Identity and Alterity," in Francis X. Clooney (ed.), New Comparative Theology: Interreligious Insights from the Next Generation. New York: T \& T Clark, 2010. Pp. 1-20.

Misrawi, Zuhairi. Al-Quran Kitab Toleransi: Inklusivisme, Pluralisme dan Multikulturalisme. Jakarta: Penerbit Fitrah, 2007.

Sani, Abdullah. Filsafat Rahman dan Rahim dalam Ketuhanan Y.M.E. Jakarta: Bulan Bintang, 1976.

Sajjad H. Rizvi, "The Existential Breath of Al-Rahman and the Munificent Grace of Al-Rahim: The Tafsir Surat al-Fatiha of Jami and the School of Ibn Arabi," in Mustafa Shah (ed.), Tafsir Interpreting the Quran: Critical Concepts in Islamic Studies (Routledge 2003), 406-435.

Siraj, M.A. "Mercy of God as Revealed in the Quran and Islamic Scriptures," Word and Worship 49/2 (2016): 135-141.

Shihab, M. Quraish. Asma’ al-Husna vol. 1. Jakarta: Penerbit Lentera Hati, 1998. 
